\title{
INAKTIVASI BAKTERI ESCHERICHIA COLI AIR SUMUR MENGGUNAKAN DISINFEKTAN KAPORIT
}

\author{
Puti Sri Komala dan Ajeng Yanarosanti \\ Laboratorium Air Jurusan Teknik Lingkungan Universitas Andalas \\ Email: putisrikomala@ft.unand.ac.id
}

\begin{abstract}
ABSTRAK
Air sumur merupakan salah satu sumber air minum terpenting bagi masyarakat, terutama bagi mereka yang tidak dilayani oleh pelayanan kota. Adanya kandungan bakteri Escherichia coli dalam air sumur dapat menjadi penyebab waterborne disease. Kaporit merupakan jenis disinfektan yang dapat digunakan untuk menyisihkan kandungan bakteri E.coli di dalam air sumur. Dalam percobaan ini dilakukan disinfeksi pada larutan artifisial dan sampel air sumur kawasan Purus. Pada percobaan larutan artifisial diperoleh dosis optimum kaporit yaitu $50 \mathrm{mg} / \mathrm{l}$ dengan waktu kontak 30 menit untuk menyisihkan bakteri E.coli dari $>1,6.10^{5} \mathrm{sel} / 100 \mathrm{ml}$ menjadi $0 \mathrm{sel} / 100 \mathrm{ml}$. Laju inaktivasi bakteri E.coli pada waktu kontak 10 menit untuk tiap dosis kaporit berkisar antara 2,6-log-3-log. Disinfeksi sampel air sumur kawasan Purus pada kondisi optimum menunjukkan hasil yang tidak jauh berbeda dengan disinfeksi larutan artifisial.
\end{abstract}

Kata Kunci: air sumur, disinfektan, E.coli, larutan artifisial

\section{ABSTRACT}

Well water is one of the most important sources of drinking water for the community, especially for those who are not served by municipal services. The presence of Escherichia coli bacteria content in well water can cause waterborne disease. Chlorine is a disinfectant types that can be used to eliminate E. coli bacteria in the water wells. In the experiments disinfection in artificial solution and well water from Purus region was carried out. In artificial solutin the optimum dose of chlorine $50 \mathrm{mg} / \mathrm{l}$ with a contact time of 30 minutes was obtained to eliminate E. coli from $>1,6.10^{5}$ cells $/ 100 \mathrm{ml}$ to 0 cells/100 $\mathrm{ml}$. The inactivity rate of E. coli at first 10 minutes contact time for each dose of chlorine was in range of 2,6-log-3-log. Disinfection of the well water of the Purus region in optimum condition showed that were not much different from the disinfecting solution artificially.

Keywords: water well, disinfectan, E.coli, artificial solution. 


\section{PENDAHULUAN}

Di Indonesia air sumur merupakan salah satu sumber air minum yang terpenting bagi masyarakat, khususnya bagi mereka yang tidak mendapat akses pelayanan air minum. Untuk mendapatkan sumber air tersebut umumnya masyarakat membuat sumur gali (Said, 1999). Hal ini juga dipertegas oleh Chandra (2007), bahwa $45 \%$ masyarakat di Indonesia menggunakan sumur sebagai sarana air bersih, dan $75 \%$ diantaranya menggunakan sumur gali.

Air yang layak diminum harus memenuhi standar persyaratan fisika, kimia, dan bakteriologis (Said, 1999). Air yang tidak memenuhi persyaratan bakteriologis menjadi salah satu penyebab waterborne disease. Parameter yang digunakan dalam persyaratan bakteriologis ini diukur melalui kandungan bakteri Escherichia coli (Suriawiria, 2005).

Dengan kondisi sanitasi lingkungan yang umumnya belum memenuhi persyaratan, air sumur yang digunakan penduduk diperkirakan sebagian dalam kondisi tercemar. Hal ini juga dilaporkan oleh DeSimone, dkk (2009) dalam penelitian air sumur domestik di USA, bahwa dari 397 sumur yang diteliti, 34 persen terdapat total Coliform, dan E.coli terdeteksi di 7,9 persen dari 378 sumur domestik. Kontaminan dapat berasal dari aktivitas manusia maupun penggunaan lahan saat itu atau sebelumnya.

Kandungan bakteri E.coli dalam air dapat dihilangkan dengan cara disinfeksi (Linsley, 1995). Kaporit dengan rumus kimia $\mathrm{Ca}(\mathrm{OCl})_{2}$ merupakan disinfektan yang sering digunakan dalam disinfeksi karena cukup efektif dan terjangkau dari segi ekonomi, bersifat stabil serta dapat disimpan lebih lama (Surbakti, 1987).

Kawasan Purus merupakan salah satu kawasan di Kecamatan Padang Barat dengan pemukiman padat sehingga kebutuhan akan air bersih relatif tinggi. Namun daerah ini belum semuanya terlayani oleh PDAM Padang. Terdapat 2.334 rumah tangga pada kecamatan tersebut yang menggunakan sumur sebagai sumber air minum (Bapedalda, 2010). Dilihat dari kondisi pemukiman di kawasan Purus serta saluran drainase dan riol yang tercampur diperkirakan dapat mencemari kondisi air sumur. Penelitian Syadikin (2003) menyatakan bahwa jumlah sel bakteri sampel air tanah kawasan Purus adalah $3.145 \mathrm{sel} / \mathrm{ml}$.

Agar air sumur tersebut layak diminum diperlukan pembubuhan disinfektan, sehingga kandungan E.coli dapat dihilangkan. Untuk itu diperlukan disinfektan yang murah, mudah diperoleh dan stabil dalam penggunaannya. Percobaan Syadikin menggunakan sinar matahari sebagai disinfektan dapat mengurangi jumlah bakteri menjadi $1.110 \mathrm{sel} / \mathrm{ml}$ $(64,71 \%)$ pada air tanah kawasan Purus dan $185 \mathrm{sel} / \mathrm{ml}(75,97 \%)$ untuk kawasan Tabing. Jumlah bakteri tersebut masih belum memenuhi batas baku mutu air minum. Disinfeksi dengan sinar matahari ini memiliki kelemahan karena bergantung pada intensitas penyinaran matahari dan keadaan cuaca.

Berdasarkan penelitian di atas, dalam penelitian ini dilakukan penggunaan disinfeksi kaporit pada air sumur untuk menyisihkan bakteri E.coli dengan variasi dosis kaporit dan waktu kontak. Keefektifan disinfektan diukur melalui laju inaktivasi bakteri, laju pertumbuhan yang terjadi selama proses disinfeksi serta nilai Ct. Kemudian, dosis dan waktu kontak optimum yang diperoleh diaplikasikan pada air sumur.

\section{METODOLOGI PENELITIAN}

\section{Bahan}

Bahan yang digunakan dalam penelitian ini yaitu bakteri Escherichia coli, air murni (aquades steril) untuk percobaan larutan artifisial, sampel air sumur kawasan Purus serta kaporit dengan kadar klor 65\% sebagai disinfektan yang dibuat dalam larutan induk dengan konsentrasi $1000 \mathrm{mg} / \mathrm{l}$. Media yang dipakai dalam pembiakkan dalam tabung uji E.coli yaitu Nutrien Agar (NA) dan Nurtrient Broth (NB) yang digunakan untuk pembiakan dalam media cair. Penetapan jumlah bakteri E.coli dalam uji MPN menggunakan media Lactose Broth (LB) dan Brilliant Green Lactose Bile Broth (BGLB). 


\section{Bakteri Escherichia coli}

Koloni Escherichia coli diperoleh dari Laboratorium Biologi MIPA, Universitas Andalas. Koloni ini dibiakkan untuk persediaan E.coli pada percobaan larutan artifisial selanjutnya. Koloni bakteri E.coli pada cawan petri dibiakkan dalam media Nutrient Agar (NA) pada tabung reaksi. Koloni bakteri diambil sebanyak 1-2 ose dan digoreskan pada media tersebut sebagai biakkan miring. Setelah itu inkubasi pada suhu kamar $\left(30^{\circ} \mathrm{C}\right)$ selama 24 jam. Selanjunya dilakukan pembiakkan pada media Nutrient Broth (NB) yang merupakan media cair dengan memasukkan 1 ose steril bakteri ke dalam erlenmeyer steril yang berisi Nutrient Broth (NB) $200 \mathrm{ml}$. Erlenmeyer dishaker pada kecepatan 80 rpm, kemudian diinkubasi pada suhu kamar selama 24 jam menggunakan incubator QL Model 12-140E.

\section{Karakterisasi Air Sumur Kawasan Purus}

Pada sampel air sumur dilakukan uji parameter fisika dan kimia diukur yaitu bau, warna, TDS, kekeruhan, temperatur, TSS, besi, mangan, COD, BOD, pH, kadmium, klorida, kesadahan, seng, sulfat, tembaga, amonia, nitrit, dan nitrat. Analisis parameter mengacu kepada Standard Methods for the Examination of Water and Wastewater (APHA, 1998). Khusus untuk parameter bakteriologis dilakukan pengukuran dengan jumlah bakteri E.coli tertinggi melalui uji MPN.

\section{Percobaan Optimasi pada Larutan Artifisial}

Pecobaan optimasi dilakukan untuk mendapatkan kondisi optimum yaitu dosis kaporit dan waktu kontak optimum dalam penyisihan bakteri E.coli. Jumlah bakteri E.coli awal yang digunakan sesuai dengan jumlah kandungan E.coli yang terukur pada sampel air sumur. Untuk menentukan rentang variasi dosis kaporit terlebih dahulu dihitung nilai kebutuhan klor. Kebutuhan klor adalah selisih antara dosis klor dengan sisa klor sesuai dengan persamaan 1 (Lee, 2007).

kebutuhan klor $=$ dosis klor - sisa klor $(1)$
Rentang dosis kaporit yang akan diamati berada diantara nilai kebutuhan klor hasil perhitungan dan diambil 5 variasi dosis kaporit. Nilai E.coli sampel air sumur dikategorikan tercemar atau air limbah, menurut Pant (2007) waktu kontak minimum adalah 30 menit. Namun, karena percobaan ini dosis divariasikan, maka rentang waktu kontak disinfeksi yang diambil adalah 10, 20, 30, 40, 50 menit.

Pada percobaan ini biakkan E.coli dimasukkan ke dalam aquades steril $100 \mathrm{ml}$ dalam erlenmeyer $250 \mathrm{ml}$. Masing-masing dosis kaporit dimasukkan pada erlenmeyer berbeda, mulut erlenmeyer ditutup dengan kapas dan dishaker selama waktu kontak 10, 20, 30, 40 dan 50 menit dengan kecepatan $80 \mathrm{rpm}$. Skema percobaan dapat dilihat pada Gambar 1. Jumlah E.coli setelah perlakuan untuk tiap dosis dan waktu kontak diukur dan efisiensi penyisihan dihitung dengan persamaan 2.

$$
\eta=\frac{\text { Ecoliawal-Ecolialkhir }}{\text { Ecoliawal }} \times 100 \%
$$

Pada percobaan ini diamati laju pertumbuhan bakteri yang terjadi selama proses disinfeksi menurut persamaan persamaan Monod (Benefield dkk., 2003).

$$
\operatorname{Ln} X_{t}=\ln X_{0}+\mu \mathrm{t}
$$

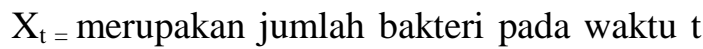
dan $X_{0}=$ jumlah bakteri awal. Dengan membandingkan jumlah E.coli jam ke-t dengan jumlah E.coli awal akan dihasilkan suatu nilai $\ln \left(\mathrm{X}_{\mathrm{t}} / \mathrm{X}_{0}\right)$. Ln $\left(\mathrm{X}_{\mathrm{t}} / \mathrm{X}_{0}\right)$ diplotkan ke dalam grafik terhadap waktu (t), sehingga diperoleh nilai laju pertumbuhan spesifik mikroorganisme $(\mu)$ dari persamaan regresi yang terbentuk.

\section{Residu Klor}

Residu klor yang diukur yaitu residu klor pada kondisi optimum pada percobaan sebelumnya. Hal ini bertujuan untuk memeriksa tingkat residu klor berada dalam batas yang dapat diterima yaitu $5 \mathrm{mg} / \mathrm{L}$ (Permenkes, 2010) untuk air minum. Pengukuran residu klor menggunakan metoda titrasi iodometri dengan persamaan 4 (APHA, 1998).

Sisa klor $=\frac{1000}{\text { ml garppl }} \times$ ml Thio Sulfat $\mathrm{x}$ N Thio Sulfat $\mathrm{x} 35,45$ 
Pada percobaan yang menggunakan larutan artifisial ini dihitung laju inaktivasi, laju pertumbuhan bakteri dan nilai C.t.

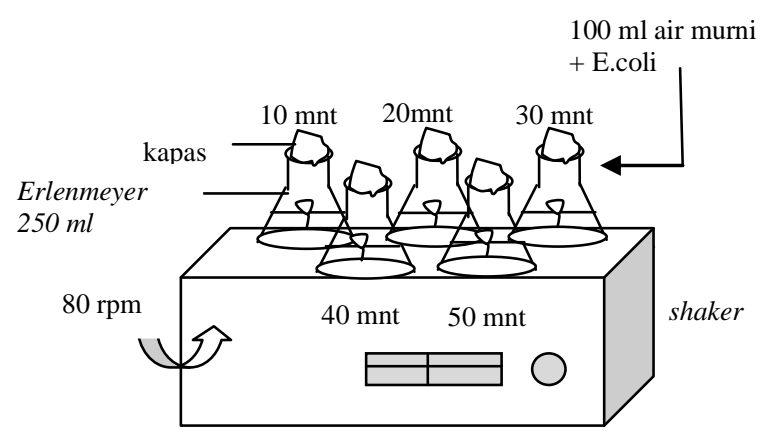

Gambar 1 Skema Percobaan Optimasi

\section{Inaktivasi Escherichia Coli}

Inaktivasi bakteri merupakan pemusnahan bakteri E.coli, dimana dalam penelitian ini menggunakan kaporit sebagai disinfektan. Perhitungan inaktivasi E.coli ini menggunakan persamaan (5), (6), (7) dan (8) (Asano dkk, 2007).

1. Laju kematian bakteri:

$$
\ln \frac{\mathrm{Nt}}{\mathrm{No}}=-\mathrm{k} \cdot \mathrm{t}
$$

2. Kontanta pemusnahan spesifik:

$$
\ln \left(\frac{\mathrm{Nt}}{\mathrm{No}}\right)=-\mathrm{k}^{\prime} \mathrm{Ct}
$$

3. Koefisien Pelarutan:

$$
\mathrm{C}^{\mathrm{n}} \mathrm{k}^{\prime}=\mathrm{k}
$$

4. $\log$ Inaktivasi $=\log \left(\frac{\mathrm{No}}{\mathrm{Nt}}\right)$

Dimana:

$\mathrm{N}_{\mathrm{o}}$ = jumlah mikroorganisme pada waktu 0

$\mathrm{N}_{\mathrm{t}}=$ jumlah mikroorganisme pada waktu $\mathrm{t}$

$\mathrm{C}=\operatorname{kosentrasi}$ disinfektan $(\mathrm{mg} / \mathrm{l})$

$\mathrm{k} \quad=$ laju kematian (1/menit)

$\mathrm{k}^{\prime}=$ konstanta pemusnahan spesifik

$$
\begin{aligned}
& (\mathrm{l} / \mathrm{mg} \cdot \mathrm{min}) \\
\mathrm{t}= & \text { waktu (menit) } \\
\mathrm{n} \quad= & \text { konstanta kelarutan }
\end{aligned}
$$

\section{Konsep Ct}

Konsep $\mathrm{Ct}$ merupakan dasar dalam teori disinfeksi yang menggambarkan efektifitas proses disinfeksi tersebut. Nilai Ct diperoleh dengan mengalikan konsentrasi disinfektan dengan waktu kontak disinfeksi (Lee dkk., 2007) yaitu:

$$
C t=\text { konstan }
$$

Dimana:

$$
\begin{aligned}
& \mathrm{C}=\text { kosentrasi disinfektan (mg/l) } \\
& \mathrm{t} \quad=\text { waktu kontak }
\end{aligned}
$$

\section{Percobaan Sampel Air Sumur pada Kondisi Optimum}

Percobaan sampel air sumur dilakukan pada kondisi optimum yaitu dosis kaporit dan waktu kontak optimum yang diperoleh dari percobaan artifisial. Percobaan ini bertujuan untuk melihat efektifitas kaporit dalam menyisihkan bakteri E.coli pada kondisi optimum dengan pengaruh senyawa penganggu disinfeksi yang terkandung di dalam sampel air sumur tersebut.

Sampel air sumur dimasukkan ke dalam erlenmeyer $250 \mathrm{ml}$ dan dibubuhkan dosis kaporit optimum hingga $100 \mathrm{ml}$. Mulut erlenmeyer ditutup dengan kapas untuk menciptakan kondisi aerob dan diaduk dengan shaker $80 \mathrm{rpm}$ selama waktu kontak optimum. Ukur jumlah E.coli, efisiensi penyisihan E.coli dan residu klor yang terbentuk.

\section{HASIL DAN PEMBAHASAN}

\section{Karakteristik Sampel Air Sumur}

Hasil analisis karakteristik sampel air sumur kawasan Purus, Padang berupa bau, warna, TDS, kekeruhan, temperatur, TSS, besi, mangan, $\mathrm{COD}, \mathrm{BOD}, \mathrm{pH}$, kadmium, klorida, kesadahan, seng, sulfat, tembaga, amonia, nitrit, dan nitrat dapat dilihat pada Tabel 1.

Pada Tabel 1 dapat dilihat kandungan TDS sampel air sumur kawasan Purus yaitu $896 \mathrm{mg} / \mathrm{l} \mathrm{melewati} \mathrm{batas} \mathrm{baku} \mathrm{mutu} \mathrm{yaitu}$ $500 \mathrm{mg} / \mathrm{l}$. Kandungan TDS yang tinggi dapat disebabkan oleh adanya pencemaran organik akibat terkontamonasi limbah domestik dan kotoran ternak. Selain itu kandungan klorida yang tinggi dalam air juga dapat menyebabkan tingginya nilai TDS 
Tabel 1. Kosentrasi Parameter Fisika, Kimia dan Biologi Air Sumur Kawasan Purus

\begin{tabular}{|c|c|c|c|}
\hline No Parameter & Satuan & $\begin{array}{c}\text { Permenkes } \\
\text { No.492/Menkes/ } \\
\text { Per/IV/2010 }\end{array}$ & $\begin{array}{c}\text { Hasil } \\
\text { Pengukuran } \\
\text { Air Sumur }\end{array}$ \\
\hline \multicolumn{4}{|l|}{ Fisika } \\
\hline 1. $\mathrm{Bau}$ & & Tidak berbau & - \\
\hline 2. Warna & TCU & 15 & 2,375 \\
\hline 3. $\mathrm{TDS}$ & $\mathrm{mg} / \mathrm{l}$ & 500 & 896 \\
\hline 4. $\quad$ Kekeruhan & NTU & 5 & 5,7 \\
\hline 5. Temperatur & ${ }^{\circ} \mathrm{C}$ & $28 \pm 3^{\circ} \mathrm{C}$ & \\
\hline 6. $\mathrm{TSS}$ & $\mathrm{mg} / \mathrm{l}$ & & 252 \\
\hline \multicolumn{4}{|l|}{ Kimia } \\
\hline 7. $\quad$ Besi & $\mathrm{mg} / \mathrm{l}$ & 0,3 & 1,103 \\
\hline 8. Mangan & $\mathrm{mg} / \mathrm{l}$ & 0,4 & 0,6 \\
\hline 9. $\mathrm{COD}$ & $\mathrm{mg} / \mathrm{l}$ & & 192 \\
\hline 10. BOD & $\mathrm{mg} / \mathrm{l}$ & & 7,1 \\
\hline 11. $\mathrm{pH}$ & $\mathrm{mg} / \mathrm{l}$ & $6,5-8,5$ & 7,5 \\
\hline 12. Kadmium & $\mathrm{mg} / \mathrm{l}$ & 0,003 & 0,267 \\
\hline 13. Klorida & $\mathrm{mg} / \mathrm{l}$ & 250 & 618,8 \\
\hline 14. Kesadahan & $\mathrm{mg} / \mathrm{l}$ & 500 & 23 \\
\hline Seng & $\mathrm{mg} / \mathrm{l}$ & 3 & 0,967 \\
\hline 15. Sulfat & $\mathrm{mg} / \mathrm{l}$ & 250 & 111,6 \\
\hline 16. Tembaga & $\mathrm{mg} / \mathrm{l}$ & 2 & 0,485 \\
\hline 17. Amonia & $\mathrm{mg} / \mathrm{l}$ & 1,5 & 1,1 \\
\hline 18. Nitrit & $\mathrm{mg} / \mathrm{l}$ & 3 & 0,849 \\
\hline 19. Nitrat & $\mathrm{mg} / \mathrm{l}$ & 50 & 1,098 \\
\hline \multicolumn{4}{|l|}{ Biologi } \\
\hline 20. E.coli & $\mathrm{sl} / 100 \mathrm{ml}$ & 0 & $>1,6.10^{5}$ \\
\hline
\end{tabular}

Kandungan klorida air sumur kawasan Purus berada di atas baku mutu yaitu $618,8 \mathrm{mg} / \mathrm{l}$. Hal ini disebabkan karena kawasan tersebut terletak di dekat pantai dan diperkirakan terjadi intrusi air laut. Air sumur kawasan Purus memiliki tingkat kekeruhan sebesar 5,7 NTU. Pada dasarnya kekeruhan ini disebabkan karena air mengandung lumpur, bahan-bahan organik serta bahan-bahan tersuspensi lainnya. Padatan tersuspensi dan kekeruhan memiliki korelasi positif yaitu semakin tinggi nilai padatan tersuspensi maka semakin tinggi pula nilai kekeruhan. Akan tetapi, tingginya padatan terlarut tidak selalu diikuti dengan tingginya kekeruhan (Effendi, 2003).
Parameter kimia seperti BOD dan COD memiliki nilai yang tinggi, mengindikasikan pencemaran bahan organik ke dalam air sumur. Kandungan klorida $618,8 \mathrm{mg} / \mathrm{l}$ pada air sumur ini diakibatkan karena Purus merupakan kawasan tepi pantai, sehingga adanya kemungkinan instrusi air laut. Nilai parameter sulfat, nitrat, nitrit dan amonia masih berada di bawah baku mutu yang telah ditetapkan. Kandungan logam besi, mangan dan kadmium melewati batas baku mutu yaitu $1,103 \mathrm{mg} / \mathrm{l}, 0,6 \mathrm{mg} / \mathrm{l}$ dan 0,267 $\mathrm{mg} / \mathrm{l}$. Air tanah secara alami mengandung banyak logam besi dan mangan yang berasal dari tanah dan batuan di sekitarnya (Saylor, 2002).

Jumlah bakteri Escherichia coli pada sampel air sumur kawasan Purus yaitu > 1,6×10 $\mathrm{sel} / 100 \mathrm{ml}$ sesuai dengan variasi tabung positif 5-5-5 pada tabel MPN. Jumlah bakteri E.coli pada sampel air sumur ini berada di luar batas baku mutu yang ditetapkan yaitu 0 sel/100 ml untuk air minum.

Penelitian Marwati (2008) pada air sumur di sekitar Puskesmas di Depansar, diperoleh kandungan rata-rata E.coli sebesar 1100 sel/100 ml, sedangkan penelitian Syadikin (2003) melaporkan kandungan bakteri E.coli air sumur di kawasan Purus yaitu 3145 $\mathrm{sel} / \mathrm{ml}$. Hal ini mengindikasikan bahwa air sumur kawasan Purus tersebut telah tercemar. Suriawiria (2003) menyatakan bahwa kehadiran mikroba patogen di dalam air akan meningkat jika kandungan bahan organik di dalam air tinggi, yang berfungsi sebagai tempat dan sumber kehidupan mikroorganisme.

Kawasan Purus merupakan kawasan padat penduduk, kondisi rumah berdesakan serta sanitasi lingkungan dan tata pemukiman yang tidak memenuhi syarat. Masyarakat yang ada kurang peduli terhadap kebersihan lingkungan, ditandai dengan banyaknya sampah yang dibuang ke selokan atau saluran drainase.

Selain itu, tingginya kandungan bakteri E.coli juga dipengaruhi oleh letak dan kondisi sumur, dimana jarak sumur dengan tempat buangan kotoran manusia/toilet yaitu 2 meter dan 6 meter dari septik tank. Berdasarkan hasil analisis statistik oleh Hasnawi (2012) diketahui bahwa aspek jarak 
sumur dengan sumber pencemar terbukti memiliki pengaruh terhadap kandungan bakteri Eschercia coli. Jarak sumur minimal 15 meter dan elevasinya harus lebih tinggi dari sumber pencemaran seperti septik tank, kandang ternak, tempat sampah, dan sebagainya (Chandra, 2007).

Kondisi sumur kurang terpelihara karena terdapat lumut pada dinding sumur. Sumur yang terbuka dan cara pengambilan air dengan timba juga dapat menjadi sumber kontaminasi. Sumur dianggap mempunyai tingkat perlindungan sanitasi yang baik, apabila tidak terdapat kontak langsung antara manusia dengan air di dalam sumur (Depkes RI, 1985).

Kadar organik yang tinggi disebabkan oleh adanya pencemaran dari limbah domestik dan industri. Pada kawasan Purus terdapat industri skala rumah tangga dan industri perhotelan yang lokasinya tidak jauh dari lokasi sumur tempat sampling. Selain itu kawasan ini menjadi tempat pariwisata tepi pantai, sehingga timbulan sampah yang dihasilkan cukup besar dan menjadi salah satu penyebab pencemaran di perairan.

\section{Bakteri Escherichia Coli}

Bakteri Escherichi coli hasil biakan pada media Nutrient Broth (NB) berdasarkan pengamatan mikroskop dapat dilihat pada Gambar 2. Hasil pengamatan mikroskop, terlihat bentuk fisiologis bakteri E.coli berbentuk batang (basil) dan dari hasil pewarnaan gram termasuk ke dalam golongan bakteri gram negatif yang ditandai dengan warna merah.

\section{Larutan Artifisial}

Nilai kebutuhan klor diperoleh berdasarkan selisih dosis klor dengan sisa klor menggunakan persamaan (1) yaitu $30 \mathrm{mg} / \mathrm{l}$. Nilai ini selanjutnya digunakan untuk menetapkan rentang variasi dosis kaporit yaitu 10, 20, 30 (kebutuhan klor), 40, dan 50 $\mathrm{mg} / \mathrm{l}$. Nilai ini lebih tinggi dibandingkan dosis optimum hasil penelitian Susanto (1998) untuk menurunkan jumlah bakteri golongan coli pada air gambut dari 250 sel/100 ml hingga $0 \mathrm{sel} / 100 \mathrm{ml}$ yaitu $19 \mathrm{mg} / \mathrm{l}$ kaporit. Menurut USEPA (2002), pada pH netral pemberian dosis ini termasuk pada kategori efluen pengolahan biologi yaitu 20$35 \mathrm{mg} / \mathrm{L}$.

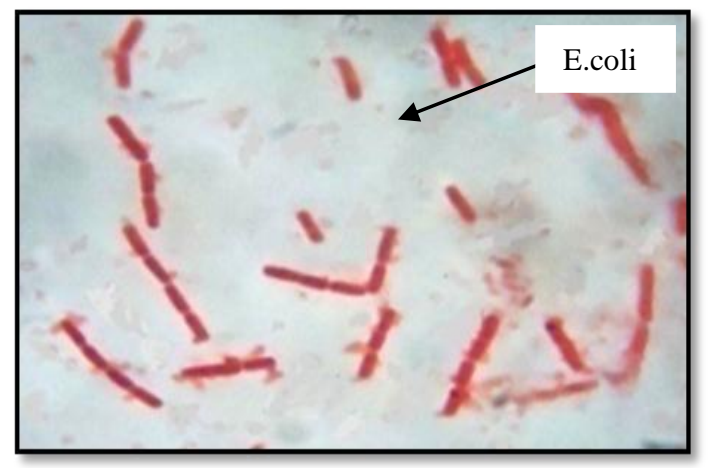

\section{Gambar 2. Bakteri Escherchia Coli pada Biakkan dengan Perbesaran 1000x}

Dosis kaporit yang tinggi untuk sampel air sumur kawasan Purus disebabkan oleh jumlah kandungan bakteri E.coli yang besar. Untuk menyisihkan jumlah mikroorganisme yang besar, terutama penyisihan mikroba patogen diperlukan dosis disinfektan yang tinggi pula (Waluyo, 2009).

Pemberian dosis $30 \mathrm{mg} / \mathrm{L}$ ini tidak dapat memusnahkan seluruh bakteri yang ada, bahkan jumlahnya masih cukup tinggi (sub bab optimasi proses disinfeksi). Oleh karena itu untuk menentukan dosis yang tepat percobaan dilanjutkan dengan penentuan dosis optimum.

\section{Optimasi Proses Disinfeksi}

Percobaan optimasi disinfeksi berlangsung dalam larutan artifisial dengan jumlah bakteri E.coli awal yaitu > 1,6 x $10^{5} \mathrm{sel} / 100$ $\mathrm{ml}$ hasil dari biakkan bakteri E.coli.

Hasil uji MPN bakteri E.coli setelah adanya pemberian dosis kaporit 10, 20, 30, 40 dan $50 \mathrm{mg} / \mathrm{l}$ untuk setiap waktu kontak 10, 20, 30, 40, 50 menit dapat dilihat pada Tabel 2.

Hasil uji MPN memperlihatkan adanya kecenderungan yang sama pada saat waktu kontak 10 menit untuk setiap penambahan dosis kaporit yaitu terjadinya penurunan drastis jumlah E.coli (Gambar 3). Dosis klor $10,20,30,40$ dan $50 \mathrm{mg} / \mathrm{l}$ mampu menurunkan kandungan E.coli awal $>1,6 \mathrm{x}$ $10^{5} \mathrm{sel} / 100 \mathrm{ml}$ masing-masing menjadi 370 , $180,180,180,360 \mathrm{sel} / 100 \mathrm{ml}$ pada waktu kontak 10 menit. Hal ini menunjukkan bahwa kaporit efektif digunakan dalam disinfeksi air pada awal berkontak. 
Penurunan jumlah bakteri diakibatkan oleh kemampuan untuk mengoksidasi yang tinggi (USEPA, 2002). Menurut USEPA apabila dimasukkan ke dalam air, kaporit akan membentuk asam hipoklorous ( $\mathrm{HOCl})$ dan kalsium hidroksida. Peningkatan $\mathrm{pH}$ akan mendorong terbentuknya $\mathrm{OCl}^{-}$, yang bersifat reaktif dan bereaksi dengan sulfida, senyawa organik, amonia dan termasuk bakteri. Oleh karena itu dengan waktu kontak yang singkat (10 menit), kaporit sudah mampu menurunkan bakteri E.coli dengan jumlah yang drastis.

Tabel 2. Hasil Uji MPN Setelah Disinfeksi pada Percobaan Larutan Artifisial

\begin{tabular}{|c|c|c|}
\hline \multirow{3}{*}{$\begin{array}{c}\text { Dosis Kaporit } \\
\text { (mg/l) }\end{array}$} & \multirow{2}{*}{$\begin{array}{c}\text { Pengenceran } \\
\text { Tabung }\end{array}$} & \multirow{2}{*}{$\begin{array}{c}\text { Jumlah E.coli } \\
\left(\text { x10 }^{2} \mathrm{sel} / 100 \mathrm{ml}\right)\end{array}$} \\
\hline & & \\
\hline & Kontrol & $>1600$ \\
\hline \multirow[t]{5}{*}{ Dosis $10 \mathrm{mg} / \mathrm{l}$} & 10 menit & 3,7 \\
\hline & 20 menit & 5,6 \\
\hline & 30 menit & 9,2 \\
\hline & 40 menit & 33 \\
\hline & 50 menit & 17 \\
\hline \multirow[t]{5}{*}{ Dosis $20 \mathrm{mg} / \mathrm{l}$} & 10 menit & 1,8 \\
\hline & 20 menit & 3,7 \\
\hline & 30 menit & 10 \\
\hline & 40 menit & 34 \\
\hline & 50 menit & 14 \\
\hline \multirow[t]{5}{*}{ Dosis $30 \mathrm{mg} / \mathrm{l}$} & 10 menit & 1,8 \\
\hline & 20 menit & 3,7 \\
\hline & 30 menit & 4 \\
\hline & 40 menit & 6,1 \\
\hline & 50 menit & 5,5 \\
\hline \multirow[t]{5}{*}{ Dosis $40 \mathrm{mg} / \mathrm{l}$} & 10 menit & 1,8 \\
\hline & 20 menit & 3,7 \\
\hline & 30 menit & 9,2 \\
\hline & 40 menit & 17 \\
\hline & 50 menit & 2 \\
\hline \multirow[t]{5}{*}{ Dosis $50 \mathrm{mg} / \mathrm{l}$} & 10 menit & 3,6 \\
\hline & 20 menit & 2 \\
\hline & 30 menit & - \\
\hline & 40 menit & - \\
\hline & 50 menit & - \\
\hline
\end{tabular}

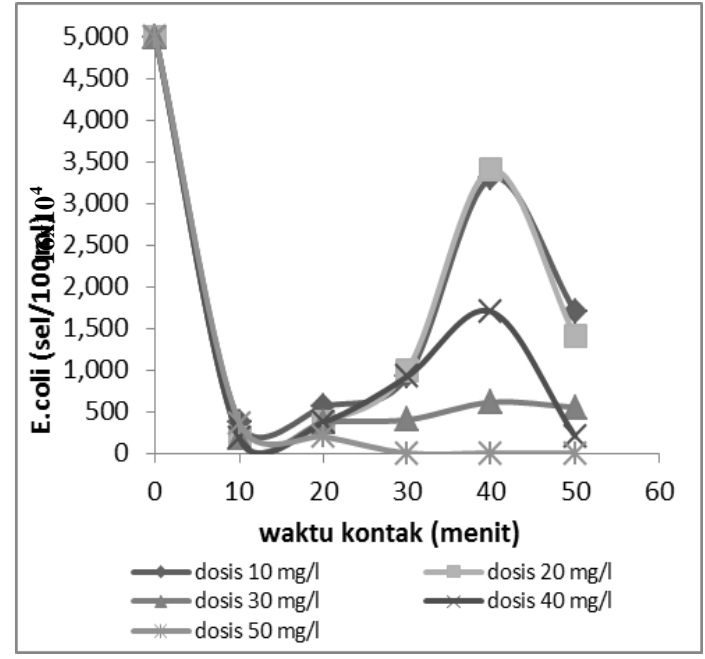

Gambar 3. Jumlah E.coli terhadap Waktu Kontak untuk Penambahan Dosis Kaporit 1050 mg/l pada Percobaan Larutan Artifisial

Disinfektan dapat membunuh bakteri dengan menghambat sintesis protein, asam nukleat, sintesis dinding sel, menghancurkan membran plasma, serta menghentikan metabolisme (Sumbali, 2009). Hal ini mengakibatkan bakteri mati atau musnah.

Pada penambahan dosis kaporit 10-40 mg/l, jumlah E.coli yang turun drastis di 10 menit pertama mengalami peningkatan jumlah sel pada waktu kontak 20 menit menjadi 560, $370, \quad 370, \quad 370$ sel/100 $\mathrm{ml}$ dan terus meningkat hingga waktu kontak 40 menit. Daya basmi kaporit mulai berkurang atau bahkan habis, sehingga efektifitas disinfektan turun. Adanya bahan makanan bagi bakteri dari media NB dalam air dapat digunakan oleh bakteri untuk tumbuh kembali.

Pada saat waktu kontak 20 menit ini bakteri E.coli mengalami fase adaptasi. Ketika daya kaporit menurun, bakteri mulai menyesuaikan diri dengan lingkungannya dan sedikit demi sedikit mulai bertambah sesuai dengan fase lag pada kurva pertumbuhan sigmoid bakteri. Pada fase lag mikroorganisme melakukan aktivitas metabolik seperti transportasi nutrien (Sumbali, 2009).

Pada waktu kontak 30 menit untuk dosis kaporit 10-40 mg/l, bakteri berada pada fase eksponensial (fase $\log$ ). Selama fase $\log$, populasi bertambah dengan cepat secara teratur, menjadi dua kali lipat pada interval 
waktu tertentu (Pelczar, 1986). Selama periode ini kecepatan peningkatan dapat diekspresikan dengan fungsi eksponensial alami. Sel membelah dengan kecepatan konstan yang ditentukan oleh sifat intrinsik bakteri dan kondisi lingkungan. Dalam hal ini terdapat keragaman kecepatan pertumbuhan berbagai jenis mikroorganisme (Brock, 1991).

Waktu kontak 40 menit dosis kaporit 10-40 $\mathrm{mg} / \mathrm{l}$, bakteri berada pada fase statis yaitu fase dimana jumlah bakteri yang berkembang sama dengan jumlah bakteri yang mati dan terus mengalami penurunan jumlah atau memasuki fase kematian hingga waktu kontak 50 menit menjadi 1.700, $1.400,550,200$ sel/100 ml. Hal ini dikarenakan jumlah nutrien yang dibutuhkan oleh bakteri untuk pertumbuhannya semakin berkurang, adanya autolisis sel dan penurunan energi seluler sehingga banyak bakteri yang mati.

Perbedaan dapat dilihat pada dosis kaporit $50 \mathrm{mg} / \mathrm{L}$, terjadi penurunan jumlah bakteri E.coli dari menit pertama dan seterusnya hingga mencapai titik 0 pada waktu kontak 30 menit sampai waktu kontak 50 menit tidak terjadi kenaikan kembali. Hasil uji MPN memperlihatkan tidak adanya gelembung gas yang tertangkap pada tabung durham, sehingga dapat dikatakan bahwa jumlah E.coli hasil perlakuan pada waktu kontak tersebut adalah $0 \mathrm{sel} / 100 \mathrm{ml}$. Hal ini menandakan bahwa daya basmi kaporit terus bekerja hingga waktu kontak akhir.

Berdasarkan hasil penelitian di atas kondisi optimum pada percobaan larutan artifisial ini berada pada pemberian dosis kaporit $50 \mathrm{mg} / \mathrm{l}$ dan waktu kontak 30 menit karena disinfektan kaporit dapat menyisihkan kandungan E.coli dalam larutan menjadi 0 $\mathrm{sel} / 100 \mathrm{ml}$.

\section{Laju Pertumbuhan E.coli}

Meskipun disinfektan dapat membasmi sebagian besar E.coli pada waktu kontak 10 menit pertama, namun pada waktu kontak 20, 30 dan 40 menit pertumbuhan terjadi kembali. Laju pertumbuhan spesifik bakteri pada percobaan ini berada pada waktu kontak 10, 20, 30 dan 40 menit untuk dosis kaporit 10, 20, 30, serta $40 \mathrm{mg} / \mathrm{l}$. Melalui perhitungaan dengan persamaan Monod (4) diperoleh laju pertumbuhan bakteri pada fase eksponensial.

Contoh perhitungan laju pertumbuhan E.coli untuk dosis kaporit $10 \mathrm{mg} / \mathrm{l}$ waktu kontak 20 menit:

$$
\begin{array}{cr}
\mathrm{X}_{20} & : 560 \mathrm{sel} / 100 \mathrm{ml} \\
\mathrm{X}_{10} & : 370 \mathrm{sel} / 100 \mathrm{ml} \\
\frac{\mathrm{Xt}}{\mathrm{X} 0}=\frac{560 \mathrm{sel} 100 \mathrm{ml}}{370 \mathrm{sel} / 100 \mathrm{ml}}=1,514
\end{array}
$$

$\operatorname{Ln} \mathrm{Xt} / \mathrm{Xo}=\ln 1,514=0,414$

Hasil $\ln \left(\mathrm{X}_{\mathrm{t}} / \mathrm{X}_{0}\right)$ yaitu 0,414 dilinierisasikan terhadap waktu sesuai dengan Gambar 4 sehingga didapat kemiringan dari kurva. Dari linierisasi tersebut diperoleh nilai laju pertumbuhan spesifik E.coli $(\mu)$ sebesar 0,07/menit. Hasil perhitungan laju pertumbuhan spesifik E.coli untuk dosis kaporit 10-40 mg/l waktu kontak 10-40 menit dapat dilihat pada Tabel 3.

Pada Tabel 3 dapat dilihat tidak ada perbedaan signifikan antara laju pertumbuhan untuk semua dosis kaporit 10$40 \mathrm{mg} / \mathrm{l}$. Laju pertumbuhan spesifik bakteri ditentukan untuk mengetahui kecepatan pertumbuhan sel bakteri dalam konsentrasi dimana bakteri berada. Laju pertumbuhan bakteri setelah pemberian variasi dosis kaporit memiliki nilai yang berbeda tergantung pada kemampuan metabolisme bakteri tersebut dan daya basmi kaporit pada saat itu

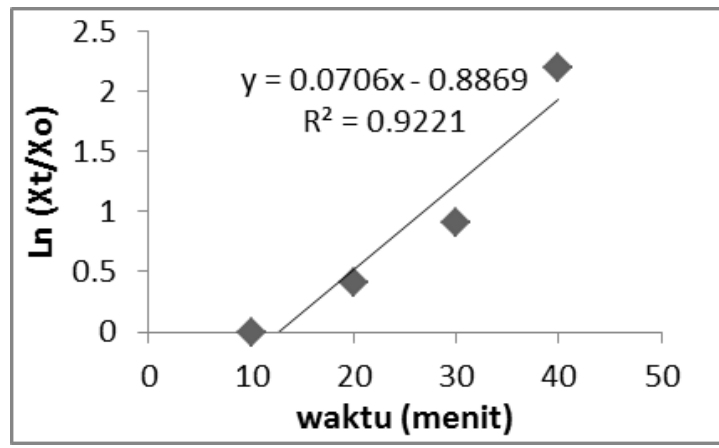

Gambar 4. Kurva Linear $\ln \left(X_{t} / X_{0}\right)$ terhadap Waktu Kontak 10-40 Menit pada Dosis Kaporit 10 mg/l 
Tabel 3. Hasil Perhitungan Laju Pertumbuhan Spesifik E.coli pada Percobaan Larutan Artifisial

\begin{tabular}{|c|c|c|c|}
\hline $\begin{array}{c}\text { Dosis } \\
\text { Kaporit }\end{array}$ & $\begin{array}{l}\text { Waktu } \\
\text { (T) }\end{array}$ & Laju Pertumbuhan $(\boldsymbol{\mu})$ & $\mathbf{r}^{2}$ \\
\hline \multirow[t]{4}{*}{$10 \mathrm{mg} / \mathrm{l}$} & $\begin{array}{c}10 \\
\text { menit }\end{array}$ & $0,07 /$ menit & 0,922 \\
\hline & $\begin{array}{c}20 \\
\text { menit }\end{array}$ & & \\
\hline & $\begin{array}{c}30 \\
\text { menit }\end{array}$ & & \\
\hline & $\begin{array}{c}40 \\
\text { menit }\end{array}$ & & \\
\hline \multirow[t]{4}{*}{$20 \mathrm{mg} / \mathrm{l}$} & $\begin{array}{c}10 \\
\text { menit }\end{array}$ & $0,098 /$ menit & 0,987 \\
\hline & $\begin{array}{c}20 \\
\text { menit }\end{array}$ & & \\
\hline & $\begin{array}{c}30 \\
\text { menit }\end{array}$ & & \\
\hline & $\begin{array}{c}40 \\
\text { menit }\end{array}$ & & \\
\hline \multirow[t]{4}{*}{$30 \mathrm{mg} / \mathrm{l}$} & $\begin{array}{c}10 \\
\text { menit }\end{array}$ & $0,037 /$ menit & 0,907 \\
\hline & $\begin{array}{c}20 \\
\text { menit }\end{array}$ & & \\
\hline & $\begin{array}{c}30 \\
\text { menit }\end{array}$ & & \\
\hline & $\begin{array}{c}40 \\
\text { menit }\end{array}$ & & \\
\hline \multirow[t]{4}{*}{$40 \mathrm{mg} / \mathrm{l}$} & $\begin{array}{c}10 \\
\text { menit }\end{array}$ & $0,076 /$ menit & 0,995 \\
\hline & $\begin{array}{c}20 \\
\text { menit }\end{array}$ & & \\
\hline & $\begin{array}{c}30 \\
\text { menit }\end{array}$ & & \\
\hline & $\begin{array}{c}40 \\
\text { menit }\end{array}$ & & \\
\hline
\end{tabular}

Nilai $\mu$ tinggi disebabkan karena daya bunuh disinfektan kaporit telah habis, sedangkan dalam medium masih ada sisa sumber nutrien yang dapat digunakan oleh bakteri. Kisaran laju pertumbuhan bakteri E.coli dalam penelitian ini berkisar antara 0,070,098/menit relatif tinggi dibandingkan penelitian Berney (2006) yang menguji sensitivitas laju pertumbuhan spesifik $(\mu)$ E.coli terhadap disinfeksi termal, sinar UVA dan matahari yaitu pada rentang 0,08-0,9 $\mathrm{jam}^{-1}$. Pada penelitian Berney laju pertumbuhan spesifik ditentukan sebelum percobaan, sedangkan dalam penelitian ini laju pertumbuhan spesifik ditentukan setelah percobaan.

Hasil penelitian Berney memperlihatkan $\mu$ yang lebih kecil kurang sensitif terhadap disinfektan dibandingkan dengan $\mu$ yang lebih tinggi. Jika dilihat dari dosis $40 \mathrm{mg} / \mathrm{L}$ pada penelitian ini memiliki nilai $\mu$ tidak jauh berbeda dengan nilai $\mu$ pada dosis 10 $\mathrm{mg} / \mathrm{L}$, artinya sensitivitas bakteri setelah waktu kontak 10 menit maupun 40 menit tidak terlalu besar lagi, bakteri sudah mulai dapat beradaptasi kembali ketika daya basmi kaporit telah habis. Hal yang sebaliknya terjadi pada dosis $50 \mathrm{mg} / \mathrm{L}$, baik pada waktu kontak 10 menit dan 20 menit bakteri tidak pernah mengalami kenaikan, bahkan turun terus sampai mencapai 0 pada waktu kontak 30 menit dan seterusnya. Pemberian dosis yang tinggi masih menyisakan sejumlah disinfektan yang masih efektif, sehingga tidak memungkinkan bakteri tersebut tumbuh kembali.

Rentang nilai laju pertumbuhan yang tidak jauh berbeda dengan Berney diperoleh pada penelitian Rahmadani (2013) mengenai biodegradasi terhadap zat warna reaktif azo menggunakan bakteri monokultur berkisar antara 0,02-0,1175 $\mathrm{jam}^{-1}$. Maka, nilai laju pertumbuhan yang diperoleh jauh lebih besar dari bakteri yang hidup di lingkungan toksik, yang mengindikasikan bakteri telah mampu bertahan hidup dengan baik ketika efektifitas disinfektan habis.

\section{Penyisihan E.coli}

Efisiensi penyisihan E.coli dihitung menggunakan persamaan (2). Dosis kaporit $10 \mathrm{mg} / \mathrm{l}$ dengan waktu kontak 10 menit dapat menurunkan jumlah E.coli awal yaitu $1,6.10^{5} \mathrm{sel} / 100 \mathrm{ml}$ menjadi $370 \mathrm{sel} / 100 \mathrm{ml}$ dengan nilai efisiensi penyisihan E.coli sebesar 99,8\%, namun pada waktu kontak 20 menit ke atas efisiensi menurun, mencapai yang terrendah sekitar $98 \%$ pada waktu kontak 40 menit (Gambar 5).

Penyisihan E.coli pada percobaan optimasi ini secara keseluruhan berada di atas $90 \%$. Efisiensi penyisihan untuk dosis $10 \mathrm{mg} / \mathrm{l}$ hingga $40 \mathrm{mg} / \mathrm{l}$ mengalami penurunan pada waktu kontak 20-50 menit dibandingkan nilai efisiensi pada 10 menit pertama. Hal ini ditandai dengan penambahan jumlah E.coli 
setelah waktu kontak 10 menit. Pada penambahan dosis $50 \mathrm{mg} / \mathrm{l}$, efisiensi penyisihan terus meningkat hingga 50 menit waktu kontak yaitu 99,8\%, 99,9\% dan $100 \%$. Efisiensi tertinggi diperoleh pada dosis kaporit $50 \mathrm{mg} / \mathrm{l}$ selama waktu kontak 30 menit yaitu mencapai $100 \%$.

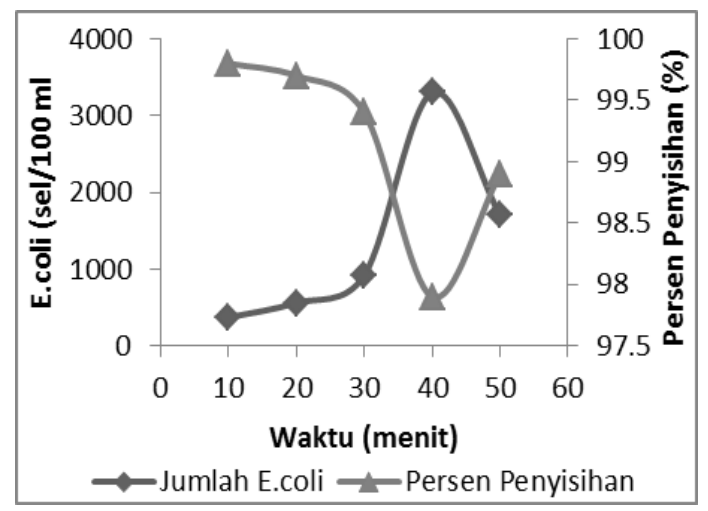

Gambar 5. Penyisihan E.coli terhadap Jumlah E.coli dan Waktu Kontak pada Dosis Kaporit $10 \mathrm{mg} / \mathrm{l}$

Penelitian Pant (2007) menggunakan kaporit pada efluen upflow anaerobic sludge blanket reactor (UASBR) dapat menurunkan E.coli dari 3,58 x $10^{5} \mathrm{MPN} / 100 \mathrm{ml}$ menjadi 0 atau penyisihan $100 \%$ dengan dosis $20 \mathrm{mg} / \mathrm{L}$ dan waktu kontak 30 menit. Akan tetapi setelah hari ke 7 sampai hari ke 14 berikutnya jumlah bakteri naik kembali. Dosis yang diperoleh Pant lebih rendah dibandingkan dosis dalam penelitian ini karena jumlah E.coli lebih rendah. Namun jika sudah tidak terdapat lagi sisa klor dalam air, bakteri akan tumbuh.

Penyisihan bakteri E.coli sebesar $5.0 \times 10^{6}$ dan $1.0 \times 10^{6} \mathrm{CFU}$ Total Coliform (TC) dan Fecal Coliform (FC) pada efluen bak sedimentasi menggunakan UV dapat menyisihkan lebih dari $80 \%$ bakteri pada 8.5 and $12 \mathrm{~mJ} / \mathrm{cm}^{2}$, sedangkan penyisihan ozon lebih rendah yaitu $72 \%$ TC dan $78 \%$ FC dengan dosis $20 \mathrm{mg} /$ menit (Bustos, 2014). Perbedaan hasil disinfeksi pada penelitian ini dapat disebabkan oleh senyawa organik dan material tersuspensi yang ada dalam air, sehingga menurunkan kinerja disinfektan.

\section{Inaktivasi Bakter E.coli}

Tingkat inaktivasi bakteri E.coli diukur pada skala logaritmik sesuai dengan persamaan 5. Secara keseluruhan nilai log inaktivasi E.coli untuk tiap penambahan dosis kaporit dapat dilihat pada Tabel 5 .

Seluruh dosis kaporit pada waktu kontak 10 menit diperoleh nilai aktivasi antara 2,6-log3-log, dimana $\mathrm{N}_{0}$ bernilai $1,6.10^{5} \mathrm{sel} / 100 \mathrm{ml}$ dan $\mathrm{N}_{\mathrm{t}}$ turun sampai yaitu 360-400 sel/100 $\mathrm{ml}$, artinya dengan efisiensi penyisihan E.coli sekitar $99,8 \%$. Inaktivasi efektif terjadi pada waktu kontak 10 menit, meskipun dalam waktu kontak ini masih menyisakan E.coli. Pada waktu kontak di atas 10 menit pada dosis 10 dan $20 \mathrm{mg} / \mathrm{L}$ bakteri memperlihatkan kurva pertumbuhan eksponensial (Gambar 3). Pada dosis disinfeksi yang kecil bakteri memperlihatkan kemampuan tumbuh yang baik setelah dosis disinfektan habis. Pada dosis 30 dan 40 $\mathrm{mg} / \mathrm{L}$, meskipun bakteri dapat tumbuh, namun jumlahnya cenderung konstan (fase stasioner). Pada dosis yang lebih tinggi, bakteri menunjukkan kemampuan resistensinya terhadap disinfektan, terlihat dari pertumbuhan yang terjadi pada waktu kontak yang lebih panjang (30, 40 dan 50 menit). Cherchi (2011) menyatakan hal yang sama, bahwa laju inaktivasi terrendah terjadi pada fase stasioner, sedangkan laju inaktivasi tertinggi terjadi pada fase eksponensial.

Tabel 5. Inaktivasi Bakteri E.coli pada Penambahan Dosis Kaporit 10-50 mg/l Waktu Kontak 10-50 Menit

\begin{tabular}{|c|c|c|c|c|c|}
\hline \multirow{2}{*}{$\begin{array}{c}\text { Dosis } \\
\text { Kaporit } \\
(\mathrm{mg} / \mathbf{l})\end{array}$} & \multicolumn{5}{|c|}{ Log Inaktivasi pada Waktu Kontak (t) } \\
\hline & $\begin{array}{c}10 \\
\text { menit }\end{array}$ & $\begin{array}{c}20 \\
\text { menit }\end{array}$ & $\begin{array}{c}30 \\
\text { menit }\end{array}$ & $\begin{array}{c}40 \\
\text { menit }\end{array}$ & $\begin{array}{c}50 \\
\text { menit }\end{array}$ \\
\hline $10 \mathrm{mg} / \mathrm{l}$ & $\begin{array}{l}2,6- \\
\log \end{array}$ & 0,18 & 0,22 & 0,55 & 0,29 \\
\hline $20 \mathrm{mg} / \mathrm{l}$ & $3-\log$ & 0,31 & 0,43 & 0,53 & $\begin{array}{c}0,39- \\
\log \end{array}$ \\
\hline $30 \mathrm{mg} / \mathrm{l}$ & $3-\log$ & 0,31 & 0,03 & 0,18 & $\begin{array}{c}0,04- \\
\log \end{array}$ \\
\hline $40 \mathrm{mg} / \mathrm{l}$ & $3-\log$ & 0,31 & 0,4 & 0,27 & $\begin{array}{c}0,93- \\
\log \end{array}$ \\
\hline $50 \mathrm{mg} / \mathrm{l}$ & $\begin{array}{l}2,6- \\
\log \end{array}$ & $\begin{array}{c}0,26- \\
\log \end{array}$ & & & \\
\hline
\end{tabular}

Setelah waktu kontak diperpanjang sampai 50 menit, pemberian dosis 20,30 dan 40 $\mathrm{mg} / \mathrm{L}$ menghasilkan kenaikan laju inaktivasi 0,04-log sampai 0,93-log. Sementara pada dosis $50 \mathrm{mg} / \mathrm{L}$ pada waktu kontak 10, 20 dan 30 menit inaktivasi terus berjalan. Inaktivasi 
tertinggi diperoleh pada dosis $50 \mathrm{mg} / \mathrm{L}$ dengan waktu kontak 30 menit yaitu mencapai 7-log. Nilai inaktivasi yang sama juga diperoleh oleh dosis $40 \mathrm{mg} / \mathrm{L}$, tetapi pada waktu kontak 50 menit.

Nilai inaktivasi pada dosis $40 \mathrm{mg} / \mathrm{L}$ pada dan $50 \mathrm{mg} / \mathrm{L}$ yang diperoleh pada penelitian ini lebih tinggi dibandingkan penelitian Tree (2003) yang menggunakan sodium hypohlorite pada efluent pengolahan primer yaitu > $5 \log$. Hasil Tree memperlihatkan dosis $30 \mathrm{mg} / \mathrm{L}$ dapat menyisihkan Escherichia coli dan Enterococcus faecalis dengan cepat (5 menit) dan sempurna dari jumlah awal masing-masing pada rentang 1 x $10^{6}-5 \times 10^{6} \mathrm{CFU}$ E. coli per $\mathrm{ml}$ dan $1 \mathrm{x}$ $10^{5}-8 \times 10^{5}$ enterococci per ml. Pada dosis yang lebih kecil $16 \mathrm{mg} / \mathrm{L}$ diperlukan waktu kontak 30 menit untuk mencapai 1,2 log reduksi.

Perbandingan empat jenis disinfeksi dilakukan oleh Bischoff (2012) menggunakan radiasi ultraviolet (UV), ozon $\left(\mathrm{O}_{3}\right)$, klorin dioksida $\left(\mathrm{ClO}_{2}\right)$ dan gas klorin hasil produksi elektrolisa $\left(\mathrm{Cl}_{2}\right)$ untuk mengolah efluen instalasi pengolahan air limbah yang diikuti dengan saringan pasir cepat. Radiasi UV berkisar pada dosis $50 \mathrm{~J} / \mathrm{m}^{2}, 20 \mathrm{mg} / \mathrm{L} \mathrm{O} \mathrm{O}_{3}$ and $12.5 \mathrm{mg} / \mathrm{L} \mathrm{Cl}_{2}$ menghasilkan reduksi $3 \mathrm{log}$, namun setelah itu terjadi kenaikan koloni kembali. Dosis $\mathrm{ClO}_{2}$ sebesar $7.5 \mathrm{mg} / \mathrm{L}$ mengurangi konsentrasi total koloni dan total coliform dsampai tidak terdeteksi dan memberi sisa disinfektan untuk pertumbuhan kembali. Menurut Tree dan peneliti lain kurva inaktivasi bifase pada mikroorganisme selama percobaan disinfeksi ditandai dengan fase inaktivasi cepat diikuti dengan inaktivasi yang lebih lambat. Hal ini dapat terjadi karena adanya subpopulasi mikroorganisme yang lebih resisten terhadap disinfeksi atau adanya kumpulan individual yang lebih resisten terhadap inaktivasi dibandingkan dengan mikroorganisme individu.

Kurva bifase juga terjadi pada percobaan ini, ditandai dengan pertumbuhan perlahan setelah waktu kontak 10 menit pada dosis 10 sampai $40 \mathrm{mg} / \mathrm{L}$, sedangkan dosis $50 \mathrm{mg} / \mathrm{L}$ terjadi pertumbuhan namun dengan bertambahnya waktu kontak kembali terjadi inaktivasi. Hasil penelitian juga memperlihatkan, bahwa dosis yang diberikan perlu memperhitungkan sisa disinfektan, agar koloni atau bakteri tidak tumbuh kembali.

\section{Konsep C.t}

Efektifitas disinfeksi yang dinyatakan dengan nilai $\mathrm{Ct}$ untuk setiap dosis kaporit dan waktu kontak dihitung dengan persamaan (9). Nilai Ct yang diperoleh dapat dilihat pada Tabel 3 .

Tabel 3. Nilai C.t pada Percobaan Optimasi

\begin{tabular}{cccccc}
\hline $\begin{array}{c}\text { Dosis } \\
\text { Kaporit } \\
(\mathbf{m g} / \mathbf{l})\end{array}$ & $\begin{array}{c}\mathbf{1 0} \\
\text { menit }\end{array}$ & $\begin{array}{c}\mathbf{2 0} \\
\text { menit }\end{array}$ & $\begin{array}{c}\mathbf{3 0} \\
\text { menit }\end{array}$ & $\begin{array}{c}\mathbf{4 0} \\
\text { menit }\end{array}$ & $\begin{array}{c}\mathbf{5 0} \\
\text { menit }\end{array}$ \\
\hline 10 & 100 & 200 & 300 & 400 & 500 \\
\hline 20 & 200 & 400 & 600 & 800 & 1000 \\
\hline 30 & 300 & 600 & 900 & 1200 & 1500 \\
\hline 40 & 400 & 800 & 1200 & 1600 & 2000 \\
\hline 50 & 500 & 1000 & 1500 & 2000 & 2500 \\
\hline
\end{tabular}

Nilai Ct yang dihasilkan untuk penyisihan bakteri sampai mendekati $100 \%$ sangat tinggi yaitu $1.500 \mathrm{mg} . \mathrm{min} / \mathrm{L}$, karena konsentrasi E.coli yang harus dihilangkan untuk memenuhi persyaratan air minum adalah nol. Kandungan E.coli dalam air sumur kawasan Purus yaitu $>1,6.10^{5}$ sel/ 100 $\mathrm{ml}$ adalah setara dengan kandungan air limbah hasil pengolahan sekunder yaitu $10^{5}$ $10^{6} \mathrm{sel} / 100 \mathrm{ml}$ (Black dan Veatch, 2010). Kandungan bakteri yang tinggi juga ditemukan pada limbah lumpur rumah sakit di Taiwan dengan Total Coliform dan Ps.aeruginosa masing-masing $1 \times 10^{7} \mathrm{cfu} / \mathrm{gr}$ (Tsai, 1999). Hasil disinfeksi hipoklorit dan klorin dioksida pada masing-masing bakteri dengan dosis $50 \mathrm{mg} / \mathrm{L}$ dan waktu kontak 50 menit telah menurunkan bakteri-bakteri tersebut hingga $10^{4} \mathrm{cfu} / \mathrm{gr}$. Penelitian lain yang dilakukan untuk disinfeksi air danau yang menggunakan gas klorin $25 \mathrm{mg} / \mathrm{L}$ dengan waktu kontak 2 menit $(\mathrm{Ct}=50$ mg.mnt/L) dapat mereduksi total coliform sebesar $1.000 \mathrm{cfu} / 100 \mathrm{ml}$ (USEPA, 1999). Nilai $\mathrm{Ct}$ yang diperlukan sebanding dengan kandungan mikroorganisme yang akan dihilangkan, di samping kandungan organik, kekeruhan dan senyawa-senyawa lain yang dapat mengganggu proses disinfeksi. Kandungan coliform yang tinggi 
menyebabkan dosis dan waktu kontak optimum untuk menyisihkan E.coli sampai ke tingkat yang diinginkan menjadi tinggi.

\section{Residu Klor}

Pengukuran residu klor dilakukan setelah tercapainya kondisi optimum dalam percobaan larutan artifisial ini yaitu pada penambahan dosis kaporit $50 \mathrm{mg} / \mathrm{l}$ selama waktu kontak 30 menit. Residu klor diukur dengan menggunakan persamaan (3). Berdasarkan hasil perhitungan pada didapatkan nilai residu klor yaitu $3,5 \mathrm{mg} / \mathrm{l}$ untuk dosis awal kaporit $50 \mathrm{mg} / \mathrm{l}$. Nilai in masih berada di bawah baku mutu persyaratan air minum. Dosis kaporit 30 $\mathrm{mg} / \mathrm{l}$ (DPC), kondisi optimum belum tercapai karena masih adanya kandungan E.coli pada waktu kontak 10-50 menit, sedangkan untuk dosis kaporit $50 \mathrm{mg} / \mathrm{l}$ dapat menyisihkan bakteri E.coli hingga 100\%. Dosis yang terlalu tinggi pun tidak diinginkan, karena kemungkinan terbentuknya hasil produk sampingan disinfeksi yang bersifat toksik (Bischoff, 2012).

\section{Kinerja Disinfektan Kaporit pada Air Sumur Kawasan Purus}

Pembubuhan disinfeksi pada kondisi optimum pada sampel air sumur kawasan Purus, dapat menyisihkan kandungan E.coli air sumur hingga 99,9\% dengan kadar residu klor $0,4 \mathrm{mg} / \mathrm{l}$. Nilai ini masih berada di bawah baku mutu. Efisiensi penyisihan E.coli air sumur dapat dikatakan tidak jauh berbeda dengan penyisihan E.coli air artificial. Perbedaan dapat disebabkan adanya beberapa senyawa-senyawa lain dalam air sumur seperti logam besi dan mangan yang tinggi, serta kandungan TDS dan kekeruhan serta senyawa organik yang melewati batas baku mutu yang akan bereaksi dengan klorin bebas, sehingga menurunkan kinerja disinfeksi (USEPA, 2002)

\section{SIMPULAN}

Dari hasil-hasil yang didapatkan pada penelitian efektifitas disinfektan kaporit dalam penyisihan bakteri Escherichia coli air sumur kawasan Purus dapat disimpulkan beberapa hal berikut:
1. Kandungan bakteri E.coli dalam air sumur kawasan Purus yaitu $>1,6.10^{5} \mathrm{sel} /$ $100 \mathrm{ml}$ melebihi baku mutu;

2. Dosis kaporit optimum dalam disinfeksi air sumur ini adalah $50 \mathrm{mg} / \mathrm{l}$ dengan waktu kontak 30 menit yang memiliki laju inaktivasi 7-log.;

3. Rata-rata laju kematian pada waktu kontak 10 menit pertama untuk tiap dosis kaporit yaitu $0,607,0,679,0,679,0,679$, 0,679 dan 0,610 /menit, sedangkan waktu kontak 10, 20, 30 dan 40 menit pada pembubuhan dosis 10-40 $\mathrm{mg} / \mathrm{l}$ terjadi kenaikan bakteri dengan laju pertumbuhan masing-masing 0,07, 0,098, 0,037, dan 0,076/menit

4. Efektifitas penyisihan E.coli pada kondisi optimum pada larutan artifisial mencapai $100 \%$ dengan jumlah awal E.coli $>1,6 \mathrm{x}$ $10^{2} \mathrm{sel} / 100 \mathrm{ml}$, sedangkan pada sampel air sumur pada kondisi optimum efisiensi penyisihan $99,9 \%$ dengan jumlah E.coli akhir yaitu $180 \mathrm{sel} / 100 \mathrm{ml}$ dan sisa klor sebesar $0,4 \mathrm{mg} / \mathrm{l}$.

\section{DAFTAR PUSTAKA}

American Public Health Association, 1998, Standard Methods for the Examination of Water and Wastewater, A.D. Eaton, L.S. Clesceri, A.E. Greenberg, (Eds.), $20^{\text {th }}$ ed., Washington D.C.

Asano, T., Burton, F., Leverenz, H. dan Tsuchihashi, R., 2007, Water Reuse: Issues, Technologies, and Applications, New York: McGraw Hill company. Inc.

Bapedalda, 2010, Buku Data Status Lingkungan Hidup Daerah Kota Padang Tahun 2010, Padang: Pemerintah Kota Padang Provinsi Sumatera Barat.

Benefield, L.D. dan Randall, C.W., 1980, Biological Process Design for Wastewater Treatment, Prentice-Hall, Inc., Englewood Cliffs, N.J.

Bischoff, A., Cornel, P., dan Wagner, M., 2012, Choosing the most appropriate technique for wastewater disinfection parallel investigation of four disinfection systems with different preceding treatment processes, Water Practice \& Technology, Vol 7 No 3, doi:10.2166/wpt.2012.054 
Black dan Veatch Corporation. (eds), 2010, White's Handbook of Chlorination and Alternative Disinfectants, Fifth Edition. John Wiley \& Sons, Inc.

Brock, T.D. dan Madigan, M.T., 1991, Biology of Microorganisms, Sixth ed. Prentice-Hall International,Inc.

Bustos, Y., Vaca, M., López, R., Bandala, E., Torres, L., Rojas-Valencia, N., 2014, Disinfection of Primary Municipal Wastewater Effluents Using Continuous UV and Ozone Treatment, Journal of Water Resource and Protection, vol 6, pp.16-21, Published Online January 2014 (http://www.scirp.org/journal/jwarp)

Chandra, B., 2007, Pengantar Kesehatan Lingkungan, Jakarta: Penerbit Buku Kedokteran EGC.

Cherchi, C. dan Gu, A.Z., 2011, Effect of bacterial growth stage on resistance to chlorine desinfection, Water Science \& Technology, vol 64, no.1, pp.7-13.

Depkes R.I., 1985, Peraturan Menteri Kesehatan RI Nomor: 239/Menkes/Per/V/ 1985. Jakarta : Depkes R.I.

Depkes R.I., 2010, Peraturan Menteri Kesehatan Republik Indonesia Nomor 492 Tentang Persyaratan Kualitas Air Minum.

DeSimone, Leslie A., Hamilton, Pixie A., dan Gilliom, Robert J., 2009, Quality of water from domestic wells in principal aquifers of the United States, 19912004 - Overview of major findings: U.S. Geological Survey Circular 1332, $48 \mathrm{p}$

Effendi, H., 2003, Telaah Kualitas Air Bagi Pengelolaan Sumber daya dan Lingkungan Perairan, Yogyakarta: Kanisius.

Hasnawi, H., 2012, Pengaruh Konstruksi Sumur terhadap kandungan Bakteri E.coli pada Air Sumur Gali di Desa Dopalak Kecamatan Paleleh Kabupaten Buol. Universitas Gorontalo.

Lee, C.C. dan Lin, S.D., 2007, Handbook of Environmental Engineering Calculations, The McGraw-Hill Companies, Inc.

Linsley, R.K., 1995, Teknik Sumber Daya Air. Edisi Ketiga. Jilid 2. Jakarta: Erlangga
Marwati, M.N., Mardani, N.K., dan Sudra, K.I., 2008, Kualitas Air Sumur Gali Ditinjau dari Kondisi Lingkungan Fisik dan Perilaku Masyarakat di Wilayah Puskesmas I Denpasar Selatan, Unud: Politeknik Kesehatan Denpasar Jurusan Kesehatan Lingkungan.

Pant, A. dan Mittal, A.K., 2007, Disinfection of Wastewater: Comparative Evaluation of Chlorination and DHSbiotower, Journal of Environmental Biology, vol. 28, no.4, pp. 717-722.

Rahmadani, A., 2013, Biodegradasi aat Warna Azo Remazol Black 5 menggunakan limbah tempe sebagai ko-substrat oleh spesies-spesies monokultur dan pengaruhnya terhadap penyisihan senyawa Nitrogen, Tugas Akhir S1, Teknik Lingkungan Universitas Andalas

Said, I.N., dan Wahyono, D.H., 1999, Cara Pengolahan Air Sumur Untuk Kebutuhan Air Minum, Kelompok Teknologi Pengelolaan Air Bersih dan Limbah Cair. Jakarta: Direktorat Teknologi Lingkungan, Deputi Bidang Teknologi Informasi, Energi, Material dan Lingkungan Badan Pengkajian Dan Penerapan Teknologi.

Saylor, J. dan Patterson, N., 2002. Iron, Manganese, and Sulfate Concentrations in Treated and Untreated Water Samples of Wells at the Raystown Field Station, Journal of Ecological Research, vol.4, pp. 52-56.

Sumbali, G. dan Mehrotra, R.S., 2009, Principle of Microbiology. New Delhi: McGraw Hill.

Surbakti, B.M., 1987, Air Minum Sehat, Surakarta : CV Mutiara Solo.

Suriawiria, U., 2003, Mikrobiologi Air dan Dasar-Dasar Pengolahan Buangan Secara Biologis. Bandung, Alumni.

Suriawiria, U., 2005, Air dalam Kehidupan dan Lingkungan yang Sehat, Bandung: PT. Alumni.

Sururi, R.M., Rachmawati S.Dj., dan Solihah, M. 2008. Perbandingan Efektifitas Klor dan Ozon Sebagai Disinfektan pada Sampel Air Dari Unit Filtrasi Instalasi PDAM Kota Bandung, Lampung: Prosiding Seminar Nasional Sains dan 
Teknologi II 2008 Universitas Lampung.

Susanto, E., 1998, Kajian Tentang Dosis Optimal Kaporit Terhadap Efektivitas Penurunan Angka Kuman Golongan Coli Pada Air Gambut di Desa Semelagi Kec. Selakau Kab. Sambas. Univ Diponegoro.

Syadikin, A.R., 2003, Studi Tingkat Penyisihan Bakteri Dalam Air Peruntukan Air Minum dengan Menggunakan Sinar Matahari, Tugas Akhir S1, Teknik Lingkungan, Padang: Universitas Andalas, Padang.

Tsai, C.T., dan Lin, T.S., 1999, Disinfection of hospital waste sludge using hypochlorite and chlorine dioxide. Journal of Applied Microbiology, Vol. 86, pp. 827-833.
Tree, J.A., Adams, M.R., dan Lees, D.N., 2003, Chlorination of Indicator Bacteria and Viruses in Primary Sewage Effluent, Applied and Environmental Microbiology, Vol. 69, No. 4, pp. 2038-2043.

USEPA, 2002, Onsite Wastewater Treatment Sistems Technology Fact Sheet 4: Effluent Disinfection Processes, TFS-17-TFS-22, EPA/625/R-00/008, February.

USEPA, 1999, Combined Sewer Overflow Technology Fact Sheet: Chlorine Disinfection, EPA 832-F-99-034 September

Waluyo, L., 2008, Teknik dan Metode Dasar dalam Mikrobiologi, Universitas Muhammadiyah, Malang Press. 